\title{
PENGEMBANGAN METODE ELEKTRODEPOSISI UNTUK PENGAMBILAN KEMBALI PERAK DARI LIMBAH FOTORONTGEN
}

\author{
Yeti Kurniasih*, Baiq Asma Nufida, Ahmadi \\ Program Studi Pendidikan Kimia FPMIPA IKIP Mataram \\ *Author Utama, email:yetikurniasih@ikipmataram.ac.id \\ Co-author 1, email: baiq.asma@gmail.com \\ Co-author 2, email: ahmadi_kimia@yahoo.co.id
}

\begin{abstract}
Silver in its ionic form is one of the heavy metals dangerous if it is discharged into the environment or into the body of humans or other living things. Silver metal pollution sources, one of which comes from waste fixer which is a waste from the photorontgen process. However, silver in its metal form has a high economic value. Therefore, the development of techniques or methods of recovering silver from the waste solution and turning it into a metal form is important to do so that the metal does not pollute the environment and can be reused economically. One method that can be done is by electrolytic deposition or electrodeposition in which silver in the form of a silver thiosulfate complex compound in the photorontgen waste is converted to Ag metal through a redox reaction. To obtain good quality and quantity of silver deposits in the electrodeposition process, it is necessary to optimize several factors that influence, among others, optimization of potential difference, time and $\mathrm{pH}$ of the solution. This study aims to determine the effect of potential difference, time and $\mathrm{pH}$ of the solution on the efficiency of the electrodeposition process. Electrodeposition efficiency was determined based on the percentage of reduced silver mass calculated from the decrease in Ag concentration in photorontgen waste solution before and after the electrodeposition process. Based on the results of the study obtained the optimum electrodeposition process at a potential difference of $8 \mathrm{~V}$ for 75 minutes and the $\mathrm{pH}$ of the waste is 3 , where the mass percent of silver which is reduced from waste is $86.49 \%$.
\end{abstract}

Keywords:separation of silver, electrodeposition, photorontgen waste

\begin{abstract}
ABSTRAK
Perak dalam bentuk ionnya merupakansalahsatulogam berat berbahaya bila dibuang ke lingkungan atau masuk ke dalam tubuh manusia maupun makhluk hidup lain.Sumber pencemaran logam perak salah satunya berasal dari limbah fixer yang merupakan limbah dari proses fotorontgen. Namun demikian perak dalam bentuk logamnya mempunyai nilai ekonomis yang tinggi. .Oleh karena itu pengembangan teknik atau metode pengambilan kembali perak dari larutan limbah dan merubahnya menjadi dalam bentuk logamnya penting untuk dilakukan sehingga logam tersebut tidak mencemari lingkungan serta dapat dimanfaatkan kembali secara ekonomis.Salah satu metode yang dapat dilakukan adalah dengan pengendapan elektrolitik atau elektrodeposisi dimana perak dalam bentuk senyawa kompleks perak tiosulfat dalam limbah fotorontgen dirubah menjadi logam Ag melalui reaksi redoks. Untuk mendapatkan kualitas dan kuantitas deposit perak yang baik pada proses elektrodeposisi maka perlu dilakukan optimasi terhadap beberapa faktor yang mempengaruhi antara lain optimasi bedapotensial, waktudan $\mathrm{pH}$ larutan. Penelitian ini bertujuan untuk mengetahui pengaruh beda potensial, waktu dan $\mathrm{pH}$ larutan terhadap efisiensi proses elektrodeposisi. Efisiensi elektrodeposisi ditentukan berdasarkan persen massa perak tereduksi yang dihitung dari penurunan konsentrasi Ag dalam larutan limbah fotorontgen sebelum dan sesudah proses elektrodeposisi. Berdasarkan hasil penelitian diperoleh proses elektrodeposisi optimum pada beda potensial $8 \mathrm{~V}$ selama 75 menit dan pH limbah sebesar 3, dimana dihasilkanpersen massa perak yang tereduksi dari limbah sebesar 86,49\%.
\end{abstract}

Kata Kunci:Pemisahan Perak, elektrodeposisi, limbah fotorontgen 


\section{PENDAHULUAN}

Perak adalah salah satu logam mulia dan berharga yang diproduksi secara luas untuk banyak tujuan.Perak merupakan logam berwarna putih, mempunyai sifat yang mengkilap dan sangat mudah ditempa. Logam perak murnimemiliki daya hantar listrik dan panas yang tinggi, mempunyai reflektifitas optik yang tinggi serta tahan terhadap korosi[1]. Logam perak memiliki nilai ekonomis yang terbilang tinggi setelah emas dan platina sehingga logam perak sering digunakan sebagai perhiasan. Selain itu, perak juga digunakan dalam ilmu kedokteran gigi, ilmu optik, pembuatan cermin, industri dan lain-lain[2].

Penggunaan perak sebagai logam komersial yang banyak digunakan oleh masyarakat sehingga membuat kebutuhan akan perak meningkat. Produksi perak dunia dilaporkan tidak cukup untuk memenuhi kebutuhan yang terus meningkat sekitar 2-2,5 $\%$ pertahun[3]. Karena sumber alami perak yang ada di bumi masih kurang untuk memenuhi tuntutan tersebut, maka upaya untuk memenuhi kebutuhan perak melalui proses daur ulang (recovery) perlu dilakukan untuk mendapatkan logam perak murni.Sumber logam perak selain dari penambangan di alam, juga sebagian besar diperoleh dari proses daur ulang. Sekitar 25 $\%$ kebutuhan perak dunia dihasilkan dari proses daur ulang dan sebanyak $75 \%$ nya diperoleh dari daur ulang limbah fotografi [4]. Limbah yang berpotensi untuk diolah kembali kandungan peraknya adalah limbah foto rontgen. Logam perak yang bersifat fotosensitif (peka terhadap cahaya) membuatnya banyak dipakai sebagai bahan pembuatan filmfotorontgen.Pengembangan Film fotorontgenmenghasilkan limbah yang mengandung Ag berkisar antara 2.500 $6.200 \mathrm{mg} / \mathrm{L}[5]$.

Berkaitan dengan hal tersebut maka pengembangan metode recovery yang efektif diperlukanuntuk memenuhi kebutuhan dunia akan perak dan untuk mengatasi masalah lingkungan. Metode recovery yang dipilih sebaiknya selain dapat menurunkan kadar logam perak dari limbah juga dapat mengubahnya menjadi logam perak murni yang bernilai ekonomis.Berbagai teknik recovery telah dilakukan untuk memisahkan perak ( $\mathrm{Ag})$ dari limbah foto rontgen, antara lain pengendapan, adsorpsi, fotoreduksi.Metode pengendapan mengubah kompleks Ag menjadi bentuk endapan dengan penambahan agen pengendap seperti sodium sulfide, sodium borohidrida dan sodium dithionit [6]. Metode ini cukup efektif untuk mengendapkan logam, namun memerlukan pereaksi kimia yang mahal dan dapat menyebabkan pencemaran lanjutan.Metode adsorpsiprosesnya cukup sederhana dan murah, tetapi adsorben yang telah jenuh dengan ion logam dapat menjadi limbah padat yang juga berbahaya. Metode lain yang juga efektif, praktis dan murah adalah fotoreduksi. Fotoreduksi yaitu reaksi reduksi yang terjadi melalui pengikatan elektron yang berasal dari fotolisis air hasil penyinaran dengan sinarUV. Fotoreduksi ion $\mathrm{Ag}(\mathrm{I})$ dalam limbah simulasi menggunakan katalis $\mathrm{TiO}_{2}$ dilaporkan efektif. Namun untuk tujuan recovery logam $\mathrm{Ag}$ dalam limbah 
fotografi melalui reaksi fotoreduksi, penggunaan katalis $\mathrm{TiO}_{2}$ menjadi sulit dilakukan karena $\mathrm{Ag}$ menempel pada serbuk $\mathrm{TiO}_{2}$ sehingga perlu dilakukan pemurnian lebih lanjut [7].

Metode lain yang dapat digunakan untuk pengolahan limbah cair yang mengandung logam perak adalah metode elektrolisis. Metode elektrolisis merupakan metode untuk pengambilan perak dari limbah pencuci film melalui pengendapan elektrolitik, yang merubah senyawa kompleks perak tiosulfat menjadi logam Ag.Metode ini memiliki beberapa keuntungan yaitu efisiensi recovery $>90 \%$ dengan kemurnian perak yang dihasilkan $98 \%$, anoda dan katode dapat dibersihkan dan digunakan kembali, serta tidak menghasilkan polutan baru [3]. Keuntungan yang lain yaitu prosesnya yang murah, dapat dikembangkan dengan mudah untuk cakupan yang luas serta dapat dikerjakan pada suhu kamar dan substrat dapat terlapisi pada area yang luas.

Salah satu penerapan metode elektrolisis adalah elektrodeposisi. Elektrodeposisi yaitu proses pengendapan suatu zat dengan menggunakan arus listrik searah. Untuk mendapatkan kualitas deposit yang baik pada proses elektrodeposisi maka, perlu dilakukan optimasi terhadap beberapa faktor yang mempengaruhi antara lain optimasi potensial, rapat arus, waktu, suhu dan $\mathrm{pH}$ larutan [8].Elektrodeposisi secara umum menggunakan prinsip metode elektrolisis yang menggunakan larutan elektrolit sebagai tempat terjadinya proses perpindahan ion [10]. Dalam sel elektrolisis, katoda dihubungkan dengan kutub positif $(+)$ sumber arus, sedangkan anoda dihubungkan dengan kutub negatif (-) dari sumber arus. Arus listrik menyebabkan terjadinya reaksi kimia dimana arus listrik yang dialirkan ke dalam larutan elektrolit akan menyebabkan kation mengalami reduksidengan menangkap elektron dan anion akan mengalami oksidasi dengan melepaskan elektron. Sumber arus akan mendorong elektron dari anoda ke katoda. Elektron ini ditangkap oleh kation sehingga pada permukaan katoda terjadi reduksi kation dan terendapkan di katoda. Pada saat yang sama terjadi reaksi oksidasi anion di permukaan anoda. Anion melepaskan electron dan melalui anoda elektron dikembalikan ke sumber arus.

Proses elektrodeposisi dilakukan di dalam suatu bejana yang disebut sel elektrolisis. Sel elektrolisis menggunakan arus listrik untuk dapat berlangsungnya reaksi kimia.Pada sel elektrolisis, reaksi kimia tidak terjadi secara spontan tetapi melalui perbedaan potensial yang dipicu dari luar sistem.Anoda berfungsi sebagai elektroda bermuatan positif dan katoda bermuatan negatif, sehingga arus listrik mengalir dari anoda ke katoda.Sel ini terdiri dari sumber arus searah yang dihubungkan dengan kawat penghantar pada dua buah elektroda yaitu katoda dan anoda, kedua ujung elektroda dicelupkan dalam bejana yang berisi larutan elektrolit.Elektroda yang dihubungkan dengan kutub positif berfungsi sebagai anoda, sedangkan katoda adalah elektroda yang dihubungkan dengan kutub negatif.

Pengendapan menggunakan metode elektrodeposisi mengikuti hukum Faraday yang menyatakan bahwa kuat arus yang mengalir dan waktu pelapisan sebanding dengan jumlah logam yang terdekomposisi 
selama proses elektrolisis berlangsung. Berdasarkan hukum Faraday I persamaannya dapat ditulis [9], sebagai berikut :

$W=\frac{\mathrm{e} . \mathrm{I} \cdot \mathrm{t}}{\mathrm{F}}$

Keterangan :

- $\mathrm{W}=$ Massa zat yang dihasilkan (gram)

- $\mathrm{e}=$ massa ekuivalen $=\mathrm{Ar} / \mathrm{Z}=$ Massa atom relatif/ Valensi

- $\mathrm{I}=$ Kuat arus listrik (Ampere)

- $\mathrm{t}=$ Waktu elektrodeposisi (s)

- $\mathrm{F}=$ Bilangan Farraday $(\mathrm{F})$

Dari persamaan tersebut, dapat dilihat bahwa massa endapan logam yang terendapkan di katoda dipengaruhi oleh valensi kation logam, arus listrik, potensial listrik (voltase), $\mathrm{pH}$ larutan, suhu dan waktu elektrodeposisi[11]. Penelitian ini bertujuan untuk mengoptimalkan beberapa parameter tersebut untuk menghasilkan massa tereduksi perak yang optimal pada pengendapan perak dari limbah fotorontgen dengan metode elektrodeposisi.

\section{METODE PENELITIAN}

\section{Alat dan Bahan}

Adapun alat yang digunakan pada penelitian ini adalah serangkaian alat elektrodeposisi dari sumber arus DC (recitifier), elektroda tembaga sebagai katoda dan elektroda karbon sebagai anoda, gelas kimia, labu ukur, stopwatch dan Spektrofotometer Serapan Atom (SSA). Sedangkan bahan yang digunakan pada penelitian ini adalah larutan limbah fotorontgen sebagai larutan elektrolit yang akan dielektrodeposisi, larutan $\mathrm{AgNO}_{3}$ p.a. sebagai standar pengukuran $\mathrm{Ag}$, larutan $\mathrm{HNO}_{3}$ untuk mengatur $\mathrm{pH}$.

\section{Prosedur}

Proses elektrodeposisi dilakukan dengan elektrolisis terhadap $250 \mathrm{~mL}$ larutan limbah foto rontgen yang sudah diencerkan 10x. Sebagai katoda digunakan lempeng tembaga yang dihubungkan dengan kutub negatif dan sebagai anoda digunakan batang carbon yang dihubungkan dengan kutub positif.Kedua elektroda tersebut dicelupkan ke dalam larutan limbah fotorontgen sebagai larutan elektrolit. Optimasi dilakukan dengan memvariasikan beda potensial, waktu dan $\mathrm{pH}$ larutan. Rangkaian alat elektrodeposisi dapat dilihat pada gambar 1 .

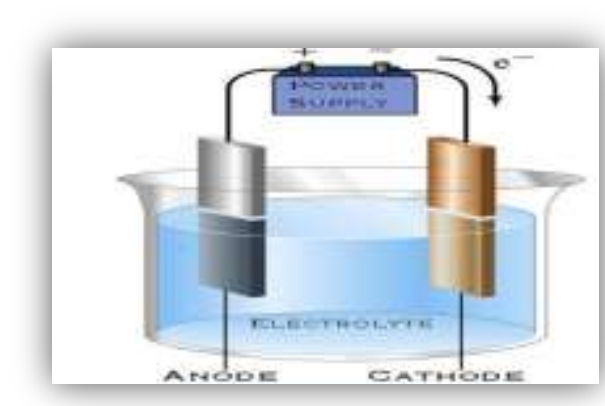

Gambar 1. Skema proses elektrodeposisi

Efisiensi elektrodeposisi ditentukan berdasarkan persen massa Ag tereduksi yang dihitung dari besarnya penurunan konsentrasi Ag pada larutan elektrolit. Penentuan konsentrasi Ag dilakukan dengan mengukur absorbansi Ag pada larutan sebelum dan sesudah proses elektrodeposisi dengan Spektrofotometer Serapan Atom (AAS) pada panjang gelombang $338.3 \mathrm{~nm}$. Untuk mengetahui persen massa Ag tereduksi pada proses elektrodeposisi dapat dihitung dengan rumus: 
$\%$ Massa Ag tereduksi $=\frac{\mathrm{Co}-\mathrm{Cx}}{\mathrm{Co}} \times 100 \%$

Keterangan :

- $\quad$ Co = Konsentrasi Ag awal sebelum elektrodeposisi

- $\mathrm{Cx}=$ Konsentrasi Ag tersisa setelah elektrodeposisi

\section{HASIL DAN PEMBAHASAN}

Pengaruh beda potensial elektrodeposisi terhadap \% massa $\mathrm{Ag}$ tereduksi

Salah satu parameter yang mempengaruhi proses elektrodeposisi dalam pengembangan metode elektrodeposisi untuk pemisahan perak dari limbah fotorontgen adalah potensialelektrodeposisi.Penggunaan beda potensial yang optimal dapat mempengaruhi persen efisiensi elektrodeposisi perak untuk pemisahan perak pada limbah foto rontgen [12]. Pada penelitian ini beda potensial yang digunakan divariasikan 4-15 volt dan hasil yang diperoleh dapat ditunjukkan pada Gambar 2.

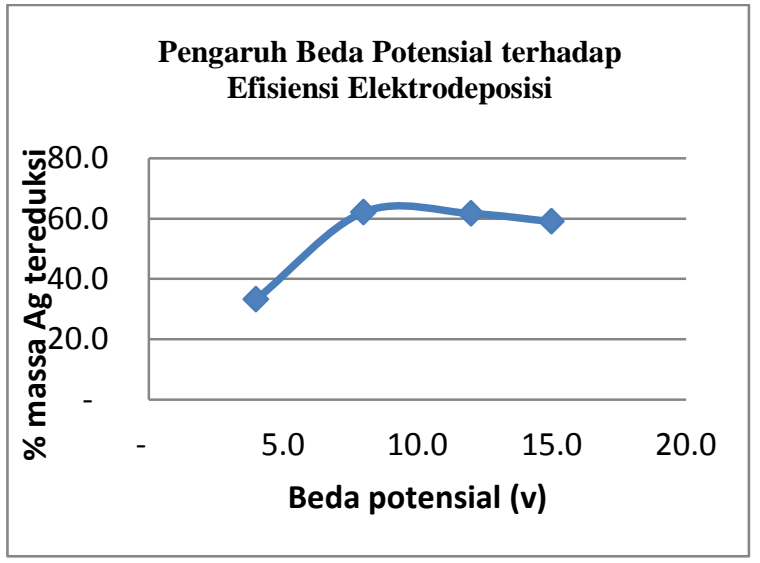

Gambar 2. Pengaruh beda potensial terhadap \% massa Ag tereduksi

Kurva pada gambar 2memperlihatkan kecenderungan pola pengaruh variasi beda potensial elektrodeposisi terhadap efisiensi pengendapan perak dari limbah fotorontgen. Efisiensi elektrodeposisi meningkat seiring dengan kenaikan beda potensial. Efisiensi elektrodeposisi paling tinggi terjadi pada penggunaan beda potensial 8 volt dengan persen massa Ag tereduksi sebesar 62,2 \%. Kenaikan voltase yang diberikan dapat meningkatkan jumlah kation logam perak yang terendap pada katoda sehingga proses elektrodepoisi perak meningkat. Namun demikian pada voltase di atas $8 \mathrm{~V}$ persen massa Ag tereduksi cenderung konstan dan mengalami sedikit penurunan. Penggunaan voltase yang terlalu tinggi mengakibatkan katoda terbakar sehingga kinerjanya menurun.

Hubungan antara massa endapan dengan jumlah arus yang digunakan pada proses elektrodeposisi berdasarkan hukum Faraday yang menyatakan bahwa massa endapan yang terbentuk dan tereduksi pada elektroda selama elektrolisis sebanding dengan jumlah arus yang mengalir dalam larutan elektrolit. Dalam hal ini dapat dikatakan bahwa massa endapan yang dihasilkan semakin meningkat jika voltase dinaikkan. Hal ini terjadi karena semakin tinggi beda potensial maka arus listrik yang dihasilkan juga meningkat. Pergerakan ion dipengaruhi oleh tegangan antar kedua elektroda dan medan listrik antar kedua elektroda. Tegangan listrik (voltase) antara elektroda menyebabkan ion ion dalam sistem bergerak ke elektroda. Hubungan antara arus listrik dan voltase dirumuskan dalam hukum Ohm dimana $\mathrm{I}=\mathrm{V} / \mathrm{R}$., sehingga jika hambatan $(R)$ yang diberikan tetap maka besarnya voltase (V) sebanding dengan besarnya arus listrik (I). 
Meningkatnya arus listrik menunjukkan meningkatnya aliran elektron pada kedua elektrode sehinggameningkatkan jumlahionlogam perak yang tereduksi dan terendapkan di katoda.

\section{Pengaruh waktu elektrodeposisi} terhadap \% massa $\mathrm{Ag}$ tereduksi

Parameter yang mempengaruhi proses elektrodeposisi dalam pengembangan metode elektrodeposisi untuk pemisahan perak dari limbah fotorontgen selain voltase elektrodeposisi adalah waktu elektrodeposisi.Pengaruh waktu elektrodeposisi terhadap efisiensi elektrodeposisi dapat dilihat pada Gambar 3.

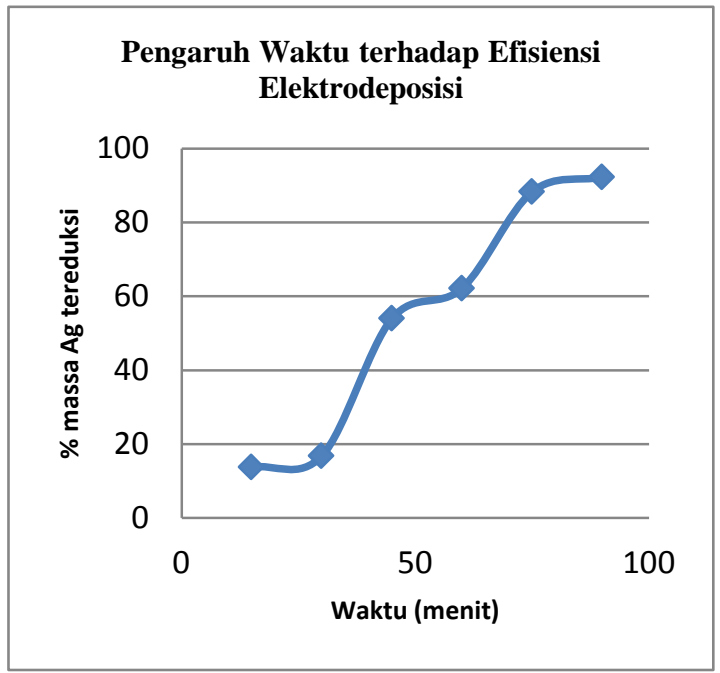

Gambar 3. Pengaruh Waktu terhadap \% massa Ag tereduksi

Gambar 3 menunjukkan bahwa waktu elektrodeposisi berpengaruh terhadap persen massa Ag tereduksi.Efisiensi elektrodeposisi meningkat seiring dengan penambahan waktu elektrodeposisi. Semakin lama waktu elektrodeposisi semakin banyak ion perak yang tereduksi dan menempel pada
katoda.Waktu elektrodeposisi selama 75 menitmemberikan efisiensi pengendapan perak sebesar86,49 \%. Hukum Faraday 1 menyatakan bahwa massa deposit logam sebanding dengan kuat arus dan waktu elektrodeposisi. Semakin lama waktu elektrodeposisi dilakukan maka semakin banyak pula jumlah endapan yang dihasilkan. Namun demikian, penambahan waktu elektrodeposisi di atas 75 menit tidak memberikan peningkatan \% massa $\mathrm{Ag}$ tereduksi secara signifikan karena tidak semua logam Ag yang tereduksi terendapkan dan menempel sempurna pada katoda.

\section{Pengaruh pH elektrolit terhadap \% massa} Ag tereduksi

Parameter proses elektrodeposisi selain voltase dan waktu juga dipengaruhi oleh $\mathrm{pH}$ (derajat keasaman) larutan elektrolit.Pada proses ini dilakukan pengaturan $\mathrm{pH}$ larutan limbah sebelum elektrodeposisi mulai dari $\mathrm{pH}$ 3-6 denngan menambahkan larutan $\mathrm{HNO}_{3}$, diperoleh hasil seperti pada Gambar 4berikut:

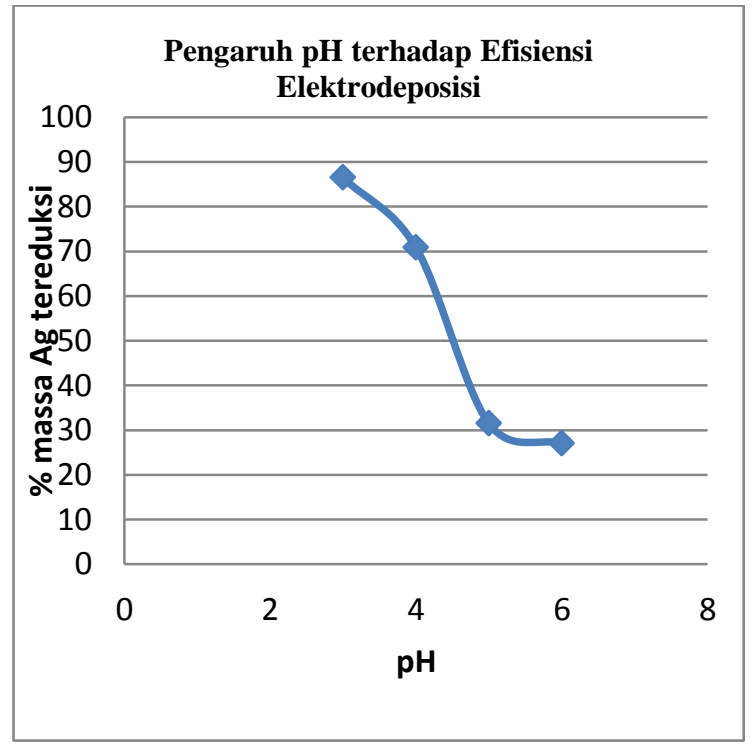

Gambar 4. Pengaruh $\mathrm{pH}$ terhadap \% massa $\mathrm{Ag}$ tereduksi 


\section{KESIMPULAN}

Kondisi optimum pemisahan perak dari limbah fotorontgen dengan teknik elektrodeposisi diperoleh pada penggunaanbeda potensial 8 volt selama 75 menit dan $\mathrm{pH}$ larutan 3 , dimana persen massa perak tereduksi sebesar $86,49 \%$.

\section{UCAPAN TERIMAKASIH}

Ucapan terima kasih ditujukan kepada Dirjen Riset dan Pengembangan Kemenristek Dikti yang telah mendanai penelitian ini melalui Program Penelitian Strategis Nasional Institusi (PSN Institusi) Tahun 2018.Ucapan terimakasih juga ditujukan kepada semua pihak yang telah membantu terlaksananya penelitian ini baik secara teknis maupun non teknis.

\section{DAFTAR PUSTAKA}

[1] Ekpunobi, U.E. Okwukogu, O.K. Anozie, A.I. Ogbuagu, A.S. Ajiwe, V.I and C.I Nweze. "Deposition and Characterization of Silver Oxide from Silver Solution Recovered from Industrial Waste". American Chemical Science Journal. Volume 3 (3) : 307313.2013.

[2] Modi, Ashish. Kishan Shukla. Jaimin Pandya. Kalpesh Parmar. " Extraction of Silver from Photographic Waste". International Journal of Emerging Technology and Advaced Enginering.Volume 2.Issue 11. P. 599-606. 2012.

[3] Masebinu, Samson O. And Edison Muzenda. " Review of Silver Recovery Techniques from Radiographic Effluent and X-ray Film Waste". Proceedings of The World Congress on Enginering and Computer Science 2014, volume (2), 2014.

[4] Shankar, S., S.V. More, R. Seeta Laxman. "Recovery of Silver from Waste X-ray Film by Alkaline Protease from Conidiobolus coronatus". Katmandu University Journal of Science, Engineering and Technology, volume (6), pp. 60-69. 2010.

[5] Widayatno, Tri. Linggar T Gupita. Senja Imaswati dan Pahlawani Novitasari. "Recovery Logam Perak dari Limbah Cair Bekas Pencucian Fotorontgen : Karakterisasi Elektrokimia". Simposium Nasional RAPI XV - FT UMS. 2016.

[6] Djunaedi, M.C., D.S. Widodo dan S. Anwar." Recovery Perak dari Limbah Fotografi melalui Membran Cair Berpendukung dengan Senyawa Pembawa Asam Di-2-etil Heksil Posfat (D2EHPA)". Reaktor, volume (11), pp. 98-103. 2007.

[7] Mahesti, Dwi. Nurrohmah. Kajian Recovery Logam Perak dari Limbah Fotografi Menggunakan Asam Organik dari Limbah Buah dan Sayur sebagai
Reduktor dan pengaruh Penambahan Gas $\mathrm{N}_{2}$. Tesis Universitas Gajah Mada. 2014.

[8] Marwati, Siti. "Pengaruh Agen Pereduksi dalam Proses Elektrodeposisi terhadap Kualitas Deposit $\mathrm{Cu}$ dan Ag., Jurnal Pendidikan Kimia Yogyakarta, pp.1-5. 2013.

[9] Agustin, W., Ambardi, P., dan Prajitno, D.H. "Elektrodeposisi Lapisan Komposit $\mathrm{Cu}_{-} \mathrm{Al}_{2} \mathrm{O}_{3}$ Dalam Larutan Cuso4 Yang Didoping Partikel Nano $\mathrm{Al}_{2} \mathrm{O}_{3}$." Jurnal Sains Materi Indonesia. Volume 14(4), pp. 272-276. 2013.

[10]Topayung, Daud. "Perngaruh Arus Listrik dan Waktu Proses terhadap Ketebalan dan Massa Lapisan yang Terbentuk pada Proses Elektroplating Pelat Baja." Manado :Jurnal IImiah Sains, volume 11(1), pp.98101. 2011.

[11]Kim., J.Y., Yu, J., Lee, J.H, and Lee, T.Y. "The Effect of lectroplating Parameters on the Composition and Morphology of Sn-Ag Solder." Journal of Electronic Materials. Volume 33(12), pp.145-1464. 2004.

[12]Marwati, S. dan Padmaningrum, R.T. "Optimasi Kondisi Elektrodeposisi Ion $\mathrm{Cu}^{2+}$ Pada Electroplating Limbah Cair Dengan Formaldehid Sebagai Agen Pereduksi."J. Sains Dasar 2016, volume5(1), pp. 62 - 70. 2016. 